\title{
Isolated fetal liver calcifications
}

\author{
izole fetal karaciğer kalsifikasyonlan
}

\author{
Özlem Pata ${ }^{1}$, Nevzat Melih Gündüz ${ }^{2}$, Cihat Ünlü ${ }^{2}$ \\ 'Department of Obstetrics and Gynecology, Faculty of Medicine, Acibadem University, Istanbul, Turkey \\ ${ }^{2}$ Department of Obstetrics and Gynaecology, Bakırköy Acıbadem Hospital, İstanbul, Turkey
}

\section{Abstract}

Hepatic calcification in the fetus is considered an uncommon occurrence and the clinical significance is not fully known. We describe five cases with isolated hepatic calcification. The causes and postnatal outcome of the fetal liver calcifications detected by ultrasound imaging are discussed. Isolated fetal liver calcifications with no aneuploidy and infection have a good prognosis.

(J Turkish-German Gynecol Assoc 2012; 13: 67-9)

Key words: Isolated fetal liver calcifications, fetal ultrasound, prognosis

Received: 5 February, 2011

Accepted: 2 July, 2011

\section{Özet}

Fetusta, hepatik kalsifikasyonlar nadir gözlenirler ve klinik önemleri ise tam olarak bilinmemektedir. Biz, beş olguda izole olarak hepatik kalsifikasyon saptadık. Bu olguları tanımlarken ultrasonografi ile saptanan fetal karaciğer kalsifikasyonlarının nedenleri ve postnatal durumları tartışıldı. Kromozomal anomali ve enfeksiyon saptanmayan izole fetal karaciğer kalsifikasyonlarının prognozları oldukça iyidir. (J Turkish-German Gynecol Assoc 2012; 13: 67-9)

Anahtar kelimeler: Fetal ultrasonografi, hepatik kalsifikasyon, prognoz

Geliş Tarihi: 05 Şubat 2011

Kabul Tarihi: 02 Temmuz 2011

\section{Introduction}

Hepatic calcifications in the fetus are hyperechogenic areas that are detected by ultrasonography imaging known as fetal liver calcifications (FLCs). Recent advances in fetal ultrasonographies have allowed these lesions to be diagnosed prenatally. These lesions have been previously described as isolated findings or in association with other abnormalities. Although isolated liver calcifications are relatively common, clinical significance and management are not known exactly $(1,2)$. We report here, a series of five cases with isolated fetal liver calcification and discuss the clinical significance.

\section{Case Report}

During 2006-2009, 1800 detailed second trimester ultrasonographies between the $18^{\text {th }}-23^{\text {rd }}$ weeks were performed in our clinic. Seven cases of FLCs were detected incidentally. Complete anomaly surveys of other organs of each case were conducted on the fetus to detect the presence of calcifications and to detect whether the calcifications were located in the liver parenchyma or liver surface. The findings were recorded. Parental and fetal cystic fibrosis (CF), mutation analysis and maternal STORCH (syphilis, cytomegalovirus, herpes virus 1 and 2, rubella, and Toxoplasma) were performed. The fetal karyotype was demonstrated by amniocentesis. The findings and results were explained and discussed with each patient. During the pregnancies, calcification size and growth of the fetus was followed and reported. After the birth, neonatal controls were carried out.

In two of the seven cases, FLCs were found to be associated with other abnormalities on ultrasonographic examination, such as ventriculomegaly, ventricular septal defect, ascites, echogenic gut. One of the two cases was reported as Trisomy 13 the other Trisomy 21. Therapeutic abortion was thus performed by consent of the parents. This study therefore focused on the prognoses of the five remaining cases. Each of the five cases was found to have isolated FLCs. In three of the five cases; the fetal calcifications were in the parenchyma (Figure 1), the others on the surface (Figure 2). In all five cases, there were no additional ultrasonographic abnormalities, no abnormal karyotypes and no genetic abnormalities of cystic fibrosis. The maternal STORCH screening was found negative for each case. The calcification size remained unchanged during the pregnancy of each case. All newborns were delivered spontaneously at term (38-41 weeks gestation) and all of the neonates were healthy. The growth development of each newborn was followed after birth for at least 6 months by pediatricians, and no developmental problems were recorded.

\section{Discussion}

The incidence of fetal hepatic calcifications is undetermined $(1,3)$. Most available information has been derived from

Address for Correspondence: Özlem Pata, Ataköy Konakları, C4- B9 34140 Bakırköy, İstanbul, Turkey

Phone: +90532 5438729 e.mail: ozpata@yahoo.com

(C) Copyright 2012 by the Turkish-German Gynecological Education and Research Foundation - Available online at www.jtgga.org doi:10.5152/jtgga.2011.66 


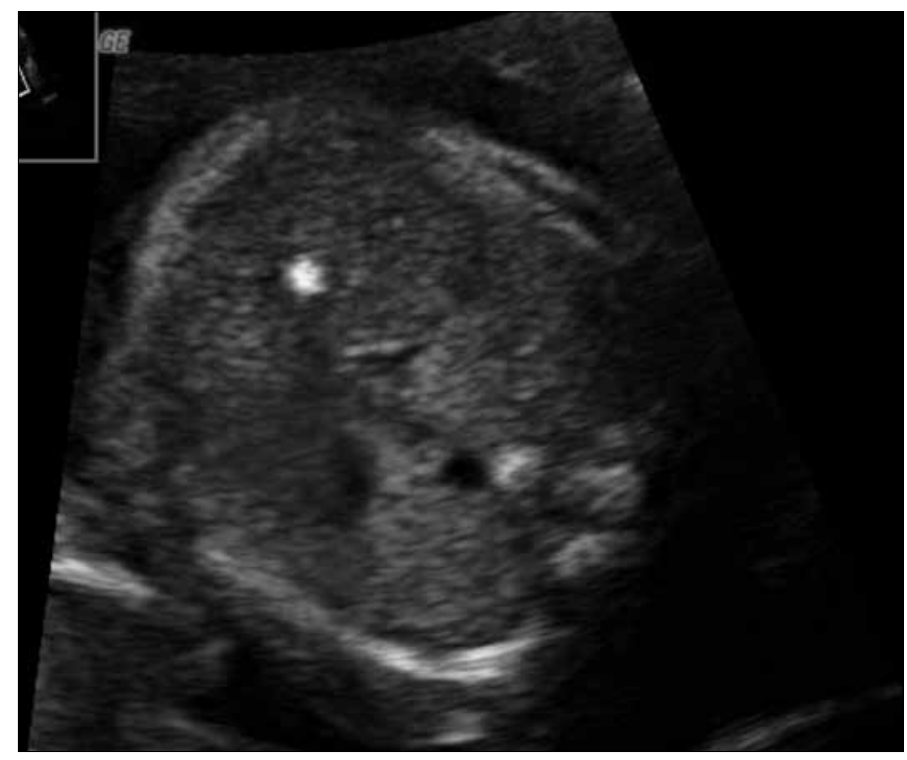

Figure 1. Parenchymal fetal liver calcification

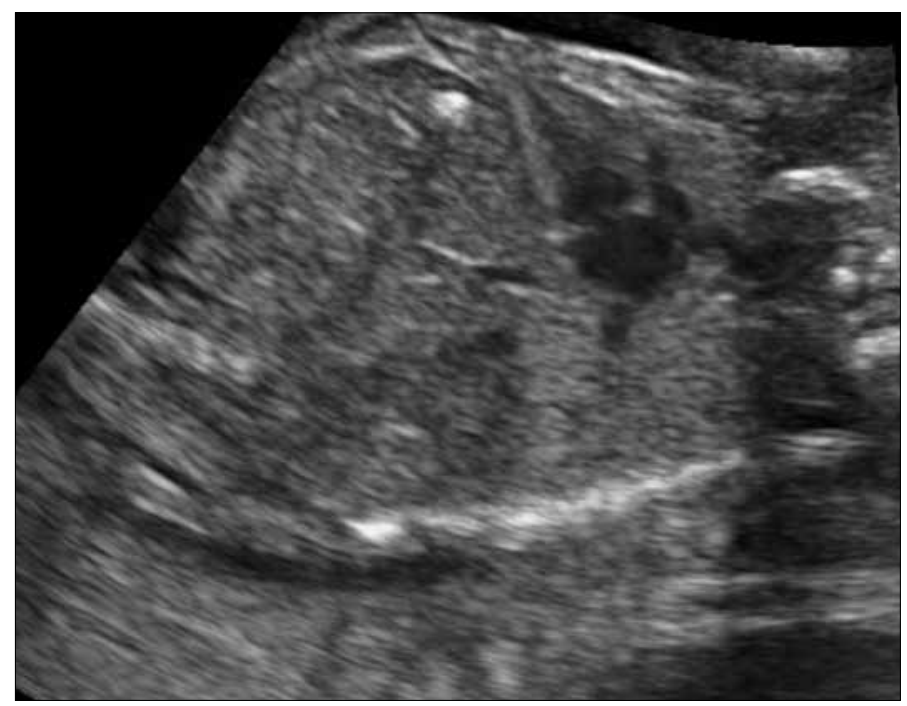

Figure 2. Surface fetal liver calcification

spontaneously aborted fetuses (4). Recent advances in ultrasonography resolution and sonographic monitoring of intrauterine pregnancies has resulted in an increased prenatal detection of these lesions. In the literature, Bronstein et al reported an incidence of 1 in 1750 at the gestational ages of 15-26 weeks (3). Similar results were found by Achiron et al. 1 in 2000, however, they emphasized that their result was biased as they included only live fetuses (2). In the current study, incidences found were higher than other publications. This may be due to the fact that our clinic is a referral center and many patients were referred with suspected fetal abnormalities.

Prenatal diagnosis of FLCs requires careful ultrasonographic, genetic and microbiological evaluation. According to the literature, possible causes for these lesions have been associated with infection, ischemic insults, portal and hepatic vein thromboemboli, tumors, chromosomal abnormalities, CF, and sludge or lithiasis in the gallbladder (1-3). Severe malformations were reported in $21-85 \%$ of these cases (1-3). Simchen et al showed that $11 / 61$ patients had abnormal karyotypes, the most common being Trisomy 13, and 10 of 11 patients with abnormal karyotypes had other abnormalities (1). Intrauterine fetal infections, especially cytomegalovirus, were associated with FLCs (3). A few previous reports concerning CF as a cause for intraabdominal fetal calcifications have been published. Thus we evaluated CF in our patients. Some authors suggested that there are no reports that link CF to prenatally detected isolated liver calcifications. Therefore, this test should be provided mainly to populations with high carrier rates of CF (1).

Fetal ultrasound hyperechogenities in the area of the liver can be categorized according to their location as peritoneal, parenchymal and vascular. It was emphasized that the location of calcification may be affected by the causes (3). Peritoneal hepatic calcifications as calcified masses on the liver surface were reported as a feature of meconium peritonitis and some of these cases were complicated by fetal CF. Parencymal hepatic calcifications have been previously associated with intrauterine infection and primary or metastatic tumors. Vascular causes have been related to the result of thrombosis or ischemia, which has also been associated with parenchymal hepatic calcification $(1,2)$. However, Simchen et al. showed that there were no differences between parenchymal and surface liver calcifications regarding the cause and outcome. They therefore divided groups with FLCs into isolated (when no other abnormalities were detected) and non-isolated (in which additional abnormalities were present) cases (1). Furthermore, FLCs may be single or multiple. In the literature, cases with multiple FLCs were associated with other abnormalities and with poor prognosis (1).

According to the literature, there are several studies that reported the outcome of fetuses with FLCs. The clinical implications from the literature review are that hepatic calcifications may represent various fetal conditions and the outcome depends on the causes and additional major abnormalities. Physicians should therefore give serious attention to this spectrum. In the current study, we present five cases of isolated fetal liver calcification with no other abnormalities; two of them were on the surface, the others in the parenchyma. The common result of all studies, including the current study, was that cases with isolated FLCs had good outcomes (1-3, 5).

In conclusion, the clinical implication from our cases and the literature suggest that isolated FLCs with no associated morphological abnormalities, abnormal karyotypes or intrauterine infection may be favorable.

\section{Conflict of interest}

No conflict of interest was declared by the authors.

\section{References}

1. Simchen MJ, Toi A, Bona M, Alkazaleh F, Ryan G, Chitayat D. Fetal hepatic calcifications:prenatal diagnosis and outcome. Am J Obstet Gynecol 2002; 187: 1617-22. [CrossRef] 
2. Achiron R, Seidman DS, Afek A, Malinger G, Lipitz S, Mashiach S, et al. Prenatal ultrasonographic diagnosis of fetal hepatic hyperechogenicities: clinical significance and implications for management. Ultrasound Obstet Gynecol 1996; 7: 251-5. [CrossRef]

3. Bronshtein M, Blazer S. Prenatal diagnosis of liver calcifications. Obstet Gynecol 1995; 86: 739-43. [CrossRef]
4. Hawass ND, el Badawi MG, Fatani JA, al-Meshari A, Makanjoula D, Edress YB. Foetal hepatic calcification. Pediatr Radiol 1990; 20: 528-35. [CrossRef]

5. Stein B, Bromley B, Michlewitz H, Miller WA, Benacerraf BR. Fetal liver calcifications: sonographic appearance and postnatal outcome. Radiology 1995; 197: 489-92.

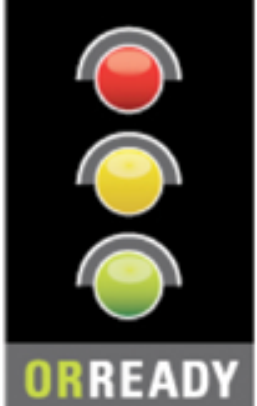

We are ORReady and support operating room safety to improve patient outcome.
ORReady is a worldwide, multi-Specialty initiative to encourage steps that are known to improve surgical outcomes and save lives.

If the suggested guidelines, which include Check Lists, Time Outs and Warm Ups are followed routinely, we estimate that Six Million patients around the world could have better outcomes.

Find out how your department and hospital can be ORReady and improve outcomes at http://www.sls.org/outcome 